tered on the seismographs in New Zealand. Of these, at least ten of the strong shocks and all the minor ones were local. The greatest of these local shocks had instrumental magnitude 61 and was felt with intensity 6 on the Modified Mercalli scale in the southern part of South Island. It occurred on May 27 at $8 \mathrm{~h}$. 54.1m., G.M.T., and the epicentre was near lat. $45 \cdot 5^{\circ} \mathrm{S}$., long. $167^{\circ} \mathrm{E}$. Three local earthquakes also attained instrumental magnitude 5 . These were on April 9 (epicentre $36 \frac{1}{2}^{\circ}$ S., $178^{\circ}$ W.), May 29 (epicentre $39 \cdot 7^{\circ} \mathrm{S} ., 174 \cdot 2^{\circ}$ E.) and June 27 (epicentre $37.55^{\circ}$ S., $177 \cdot 05^{\circ}$ E.).

\section{Smith-Mundt Grants for Study in the United States}

UNDER Public Law No. 402, Eightieth Congress (Smith-Mundt Act), a limited number of dollar grants from the United States Government are available to university teaching staff or those of equivalent academic status in other institutions and to senior research workers who wish to visit the United States for the purpose of study, research or lecturing. Candidates must be affiliated with an American institution of higher learning ; research workers must spend at least three months in the United States, and visiting lecturers at least six months or one semester; all applicants must be citizens of the United Kingdom. Successful candidates will also be awarded a Fulbright grant to cover travel from Great Britain to the United States and return. The maximum grant under the Smith-Mundt Act is 2,000 dollars a year, plus the cost of internal travel within the United States (when not covered by the Fulbright grant), plus an allowance of 10 dollars a day during this travel. The grants will operate for twelve months from June 1. Prospective candidates should write immediately to the United States Educational Commission in the United Kingdom, 55 Upper Brook Streөt, London, W.1, for the application forms, which must be returned before February 18.

\section{Scientific Film Shows at the Science Museum}

Is order to familiarize a wider public with the increasing use of scientific films, both as a means of research itself and as a means of disseminating scientific information, special film shows will be held on the third Saturday of every month in the lecture theatre of the Science Museum at South Kensington. These shows have been arranged by the Scientific Film Association and will take place at 10.45 a.m. Admission is free. At the opening meeting, on January 21, two films will be shown: "Ermites du Ciel", a French film describing the life, conditions and equipment at the Pic du Midi Observatory in the Pyrenees, and "Heating Research in Houses", produced by the Building Research Station.

\section{Third World Petroleum Congress}

The Third World Petroloum Congress will be held at The Hague, Holland, during May 28-June 6, 1951. The main headings under which papers will be presented and discussed are: (1) geology and geophysics; (2) drilling and production; (3) refining technology - (a) physico-chemicalmethods, $(b)$ methods involving change in composition; (4) petrochemicals; (5) analysis and testing ; (6) utilization of products ; (7) plant and equipment ; (8) transport, storage and distribution; (9) economics and statistics. The various sessions will be held in hotels in The Hague, and the information office will open in the Kurhaus
Hotel on May 28, 1951. Excursions to petroleum and industrial centres and to places of interest will be arranged, and social events for the evenings will be organised. The Permanent Council of the World Petroleum Congress has requested the appropriate body in each country to form a national committee which will be responsible for organising the collection of papers within its own country. For Great Britain, the Institute of Petroleum has been invited to form the national committee, and this consists of : E. A. Evans, Lieut.-Colonel S. J. M. Auld, C. Chilvers, T. Dewhurst, Prof. F. H. Garner, H. S. Gibson, H. Hyams, G. Sell, C. A. P. Southwell, H. C. Tett. Further details can be obtained from the Secretery of the Third World Petroleum Congress, Carel Van Bylandtlaan 30, Den Haag, Holland.

\section{"Low-Frequency Components of Atmospheric Pulses and their Origin"}

ReFrering to the communication by Prof. S. R. Khastgir and R. Roy in Nature of September 17, p. 488, under this title, Mr. C. E. R. Bruce, of the Electrical Research Association, 5 Wadsworth Road, Greenford, Middlesex, points out that he gave a similar and quantitative explanation of the effect in Nature, 148, 165 (1941). This communication had been overlooked by Prof. Khastgir.

\section{Announcements}

Prow. N. E. Odell, of the Department of Geology and Geography, University of British Columbia, has been appointed professor of geology in the University of Otago, Dunedin, Now Zealand.

Dr. F. D Richardson, head of the Chemistry Department of the British Iron and Steel Research Association, has been appointed Nuffeld Research Fellow in extraction metallurgy at the Royal School of Mines, London. The purpose of this new fellowship is to permit the establishment of an academic research group to work on the extraction metallurgy of both ferrous and non-ferrous metals. Within this field, Dr. Richardson intends that the researches of his team should be devoted to the thermodynamics of slag and metal solutions of importance in extractive processes.

The twenty-fifth anniversary of the granting to the Textile Institute of its Royal Charter and the fortieth anniversary of the foundation of the Institute on April 22, 1910, will be marked by a dinner to be held at Bradford on March 14.

A symposium on molecular structure and spectroscopy will be held at the Mendenhall Laboratory of Physics at the Ohio State University during June 12-17. Further information can be obtained from Prof. Harald H. Nielsen, Mendenhall Laboratory of Physics, Ohio State University, Columbus 10, Ohio.

At the invitation of the Swedish National Committee for Crystallography, the Second General Assembly and International Congress of the International Union of Crystallography will be held in Stockholm during June 27-July 3, 1951. These dates have been chosen in consultation with the Swedish National Committe and with the National Committees of all the countries adhering to the Union, and it is hoped that this early notice will make it possible for crystallographers throughout the world to arrange to attend. Further particulars of the meeting will be available in due course. 